Revista Eletrônica Geografar, Curitiba, v. 2, Resumos do VI Seminário Interno de Pós-Graduação em Geografia, p. 31-31. Junho/2007

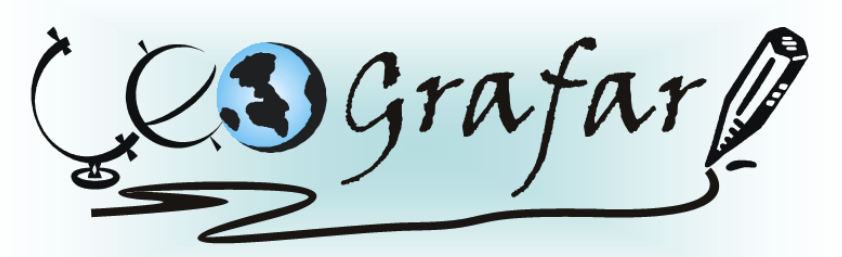

Revista Eletrônica do Programa de Pós-Graduação em Geografia - UFPR

\title{
ZONEAMENTO AMBIENTAL DA BACIA HIDROGRÁFICA DO RIO PALMEIRINHA, MUNICÍPIO DE CAMPINA GRANDE DO SUL - PR.
}

\section{GLEICI SIMIONI CORDEIRO KICHE ${ }^{1}$}

Muitos problemas ambientais referentes à qualidade e a quantidade de água estão localizados nas regiões metropolitanas brasileiras. Considerando o intenso processo de urbanização que se tem caracterizado no Brasil nas últimas décadas, as bacias hidrográficas localizadas nestas áreas estão sujeitas à maior interferência humana, principalmente das pessoas que se submetem, por questões econômicas, morar em bairros de pouca (ou nenhuma) infra-estrutura e em áreas irregulares. Adaptando a metodologia de Ross (1994), a qual se baseia no conceito de Unidades Ecodinâmicas preconizadas por Tricart (1977), e adaptando a metodologia de Mendonça (1999), ambas baseadas na Teoria Geral dos Sistemas, o presente trabalho pretende analisar a bacia hidrográfica integrando os processos naturais e antrópicos, procurando avaliar o estado de degradação ambiental, causado pelo crescimento populacional e propor medidas que visem minimizar ou reduzir os impactos ambientais presentes. A bacia hidrográfica do rio Palmeirinha está localizada na porção nordeste do município de Campina Grande do Sul - PR, pertencente à Região Metropolitana de Curitiba-RMC. Por se tratar de uma bacia hidrográfica de área mista (urbana/rural), há necessidade de adoção de princípios de conservação de recursos hídricos, pelo qual subtende as inter-relações dos fatores bióticos e abióticos do ecossistema natural, avaliando o potencial de autodepuração dos rios para propor um planejamento do uso territorial local tendo como enfoque principal a bacia hidrográfica. Disciplinar a forma de ocupação da bacia do rio Palmeirinha, assim como de outras bacias hidrográficas, proporcionando a melhora na qualidade de vida das pessoas, o zoneamento ambiental é uma forma de tentar garantir a sobrevivência dos rios e conseqüentemente das gerações futuras.

Palavras-chaves: Bacia hidrográfica, degradação ambiental, zoneamento

${ }^{1}$ Mestranda em Geografia - UFPR - email:gleicikiche@terra.com.br Orientadora: CHISATO OKA FIORI 